beetle as one). But one is constantly reminded of others in the series-that wretched lizard cooling its feet in almost ritual attitudes, the parachuting frog, the toad's anti-snake attitude, the skimmer skimming, the caves of Naracoorte, Dinosaur National Park, the lancelets feeding, and scores of others.

Please may we have soon a de luxe edition with twice the number of plates, a millionaire's edition with four times the number of plates, and a nationally assisted edition with ten times the number? Its value for schools alone would justify the expenditure of government money, and help to assuage the feelings of those who now have to teach spelling in the Universities.

A. J. Cain is Derby Professor of Zoology at the University of Liverpool, UK.

voyage was a survey of the southern shores of South America. As a naturalist attached to a naval vessel, Darwin might have gone to the Antarctic as Joseph Hooker did, to Australia and New Guinea as Huxley was to do, or perhaps not further than the eastern Mediterranean, the limit for Edward Forbes. But South America, not long freed from restrictions on scientific enquiry only penetrated by Humboldt, was a different proposition. To the prematurely judicious eye of Darwin, only 22 when the voyage began, this continent presented so very however, with products of later years at Down House, would have been no more than the work of an outstanding naturalist had it not been for the publication of The Origin of Species. Darwin then changed the direction of human thought and based his demonstration of the fact of evolution on "certain facts in the distribution of organic beings inhabiting South America, and in the geological relations of the present to the past inhabitants of that continent". From that date all that Darwin had done and thought becomes of profound interestabove all his activities during the voyage of HMS Beagle which ended on November 7, 1836, "having completed the unusually long period of five years and one hundred and thirty six days" in commission.

Apart from the Journal of Researches, his granddaughter, Lady Barlow, edited Charles Darwin's Diary of the voyage of HMS Beagle in 1933 and twelve years later unpublished letters and notebooks in Charles Darwin and the Voyage of the Beagle, with

HARDLY to be realised by that monarch or indeed by any of his subjects, yetviewed in the light of what was to come from it-the voyage of HMS Beagle could well be considered the most momentous event during the short reign of William IV. That vessel departed on her circumnavigation of the globe 18 months after he came to the throne and returned less than a year before his death and the accession of Queen Victoria. The numbers of those aware of the course and significance of this voyage have recently been vastly increased following the broadcast of the imaginatively impressive television series by BBC-TV.

Putting aside for the moment the eventual consequence in The Origin of Species, there was early appreciation of the immediate achievements of the voyage. Darwin's original account of what he saw and did was initially somewhat hidden because it formed volume 3 of the Narrative of the Surveying Voyages of HMS 'Adventure' and 'Beagle' between 1826 and 1836 published in 1839. This appeared before a wider public six years later as the Journal of Researches into the Natural History and Geology of the Countries visited during the Voyage round the World of HMS 'Beagle' under the Command of Captain FitzRoy $R N$, which a reviewer in the Quarterly Review was to describe as "One of the most interesting narratives of voyaging that it has fallen to our lot to take up, and one which will always occupy a distinguished place in the history of scientific navigation".

How fortunate it was, one may well reflect, that the prime concern of the

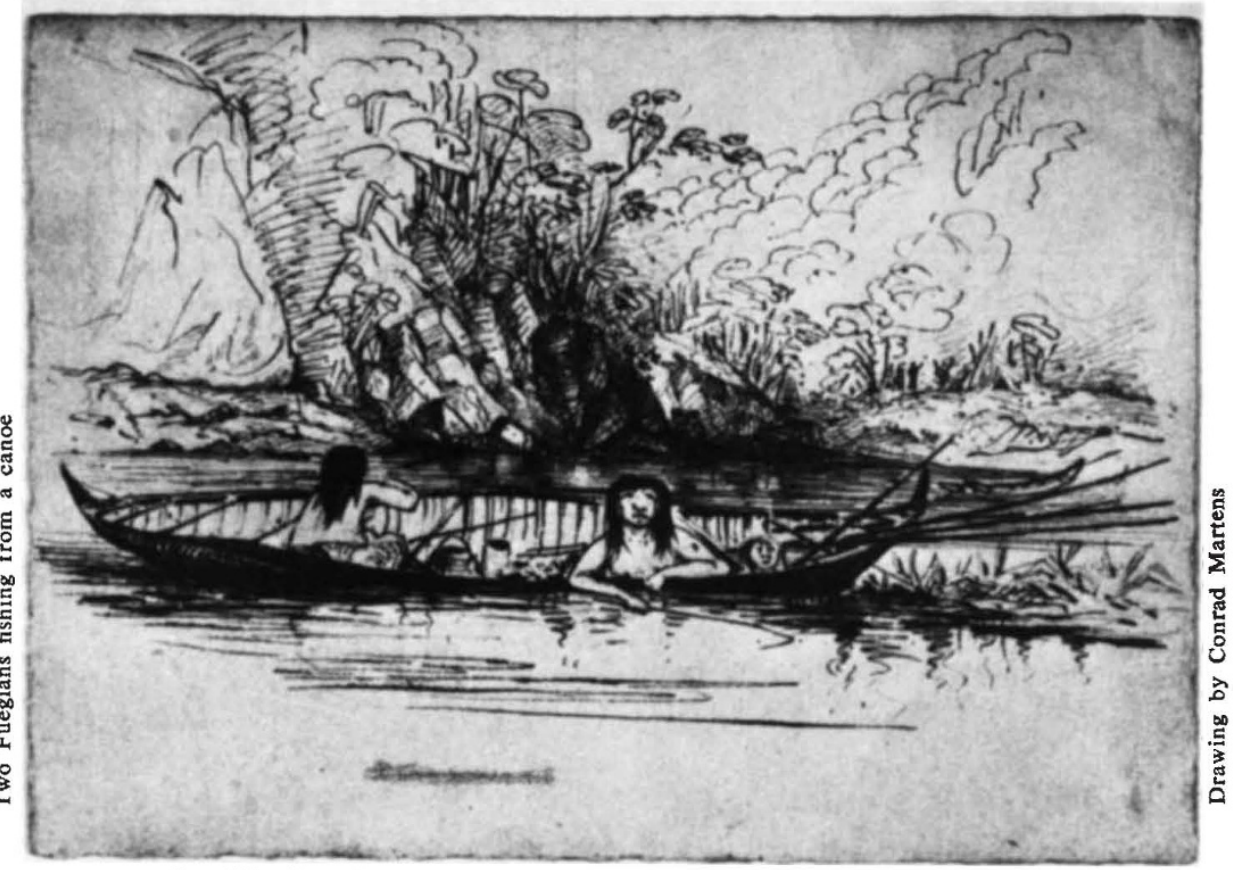

many matters for contemplationrecent earth movements, a wealth of unusual animals and plants, above all of fossil remains-during the long process, with constant re-checking, of FitzRoy's surveys. There was the final bonus of the parting visit to the Galapagos Islands before the long journey home.

After return the first scientific outcome was The Structure and Distribution of Coral Reefs, the subsidence theory a result more of his previous observations of earth movements in South America than of those on the few coral formations encountered in the Pacific and Indian Oceans. All, his letters to Henslow (1831-1860) in Darwin and Henslow: The Growth of an Idea in 1967.

The present, and most impressive, volume came initially into beingProfessor Richard Darwin Keynes, a great grandson, informs us-after a chance encounter with Dr Armando Braun Menendez at Buenos Aires in 1968. His rich collection of books, charts and pictures dealing with the exploration of the southern hemisphere was found to include two of the sketch books of Conrad Martens. Darwin may introduce him; writing to his sister Caroline from Monte Video on November 13, 1833, with initial 
reference to the first official artist, he states: "Poor Earl has never been well since leaving England and now his health is so entirely broken that he leaves us--\& $\mathrm{Mr}$ Marten, a pupil of C. Fielding \& excellent landscape drawer has joined us".

Such indeed were his qualifications as revealed by the great majority of the illustrations, many in colour, that adorn this book. They mainly depict scenes around the southern coasts because, after nine months, Martens left at Valparaiso, FitzRoy without money to employ him longer. But in of Port Desire, in the Beagle Channel, at the Santa Cruz River, at Chiloe and elswhere, we view scenes that Darwin and all aboard HMS Beagle must have gazed upon. The few pictures not by Martens include John Gould's painting of Rhea Darwinii and FitzRoy's sketch of Coquimbo in Chile, with the simple drawing of Napoleon's tomb at St Helena by Darwin's servant Syms Covington. these beautifully reproduced sketches

The skilfully edited text, aiming at a general narration of events, is a judicious blend of extracts from the Diary, with all of Darwin's letters to his father and sisters, together with those, largely on scientific matters, to Henslow. FitzRoy is represented by extracts from the second volume of the Narrative with letters, both official and personal, to Captain Francis Beaufort, Hydrographer to the Navy and under whose instructions the voyage was carried out. There are concluding passages from the Narrative in which he defends the biblical story with the record of the rockspotent evidence for evolution in Darwin's hand-all explained as a result of the flood!

Charles Darwin has been well served by his family--first by his sons, then by his granddaughter; and now a great grandson has produced the culminating tribute.

Sir Maurice Yonge is Honorary Fellow in Zoology at the University of Edinburgh, $U K$

\section{Saga of a research vessel}

\section{George Deacon}

On Almost Any Wind: The Saga of the Oceanographic Research Vessel "Atlantis". By S. Schlee. Pp301. (Cornell University Press: Ithaca and London, 1978.) $£ 10.50$.

THE Atlantis was built for the newly founded Woods Hole Oceanographic Institution in 1930-31, where, to begin with, most of the work was done in summer by scientists who held teaching appointments. Nevertheless the Trustees recognised that progress required a moderate sized ship, with reasonable living quarters, able to work in the deep oceans. H. B. Bigelow, Director of the Institution, and Columbus Iselin, general assistant and future master of the ship had much to do with her specification. She was a steel auxiliary, rigged as a ketch, with fore and aft sails, engined by a $280 \mathrm{hp}$ diesel engine. Sail was chosen for economy, long range and steadiness, though it has often been suggested that yachtsman's preference for sail had something to do with it. It was, perhaps, something of an anachronism from the start. UK oceanographers had proved Captain Scott's square- : rigged, coal-fired Discovery unsuitable for making widespread observations in $\stackrel{\circ}{\circ}$
Sorry, for copyright reasons some images on this page may not be available online

our knowledge of the water circulation in the north-western Atlantic Ocean and Caribbean Sea, of daily plankton migrations, nutrient cycles, bacterial populations in sediments, the Gulf Stream, Sargasso weed, and $\mathrm{CO}_{2}$ in atmosphere and ocean, among other basic problems. She went on to make extensive biological and physical studies of the Georges Bank area. She had also taken part in the development of a large quantitative plankton net with a triangular opening, with $50 \mathrm{ft}$ sides, and the Leavitt release gear for opening as well as closing. She began seismic exploration at sea with Maurice Ewing "who was constantly banging on the Institution's door" and was used for development of more efficient core-samplers and the bathythermograph.

She was laid up when America joined the war, and afterwards used extensively in studies of underwater acoustics and underwater explosions. Her coverage was extended to the midAtlantic ridge, the Mediterranean Sea, the South Atlantic, the deep trench west of Chile and Peru, and to the Red Sea which proved a severe test of her suitability. There were fairly hectic times when she cooperated with the Vema, Ewing's own converted yacht which is still at work though without her rigging. Progress was most rapid when specialists of different kinds worked together. "Hersey's gang. charged across the frontiers of acoustic technique and instrumentation . . like an institution within the Institution". Cooperative studies of the Gulf Stream were also very effective.

Schlee's book gives a lively and realistic account of life at sea in a small ship, based on the journals of her scientists and officers as well as the Institution's archives. She was often uncomfortable, "most of one's existence is passed exchanging one small discomfort for another". Shortage of funds was an obvious as well as concealed cause of trouble. She had a deep-sea winch from the start and a precision echo sounder in 1953, but no powered windlass or freshwater showers till 1954. She is not the only

small ship in which continued discomfort has led to bother at sea and trouble in foreign ports, but she had her share.

In 1957 most of the trans-Atlantic sections were worked by a larger fullypowered ship the Crawford, soon joined by the Chain, and in 1963 by

$\because$ the Atlantis II. The old 'A-boat' was

going down hill, but still used for tasks

\% that she could do as well as and some-

times better than larger ships. In 1966

in she was sold at a nominal charge to

the National Council for Scientific In-

o vestigation in Argentina. She was re- 